\title{
Molecular genetic defects in congenital hypothyroidism
}

\author{
Annette Grüters, Heiko Krude and Heike Biebermann \\ Paediatric Endocrinology, University Children's Hospital Charité, Augustenburger Platz 1, 13353 Berlin, Germany \\ (Correspondence should be addressed to A Grüters; Email: annette.grueters@charite.de)
}

\begin{abstract}
Recently molecular genetic defects in some cases of congenital hypothyroidism $(\mathrm{CH})$ as well as of rare cases of central hypothyroidism have been identified. These studies have led to the description of so far unexplained forms of these disorders. In some patients with $\mathrm{CH}$ early diagnosis by newborn screening and early treatment was not able to lead to a normal mental development. This could subsequently be explained by molecular defects of transcription factors (FOXE-1/FKHL15, NKX2.1) which are important not only for the embryonic development of the thyroid gland but also for other organs including the central nervous system (CNS). These findings will help in understanding the critical role of thyroid hormones in the pre-and postnatal CNS development. However, many questions regarding the molecular defects and their consequences in the majority of patients with $\mathrm{CH}$ still remain open and will be addressed in this article.
\end{abstract}

European Journal of Endocrinology 151 U39-U44

\section{Epidemiology of congenital hypothyroidism (CH)}

Screening programmes report a rather constant incidence of permanent primary $\mathrm{CH}$ of 1:3000 to 1:4000 newborns with the exception of a decreased prevalence in the African-American and an increased prevalence in the Hispanic population (1). Girls are more frequently affected than boys (female to male ratios ranging from $2: 1$ to $4: 1)(2,3)$. Table 1 shows the classification and diagnosis of the different types of permanent $\mathrm{CH}$.

The most common aetiology of primary $\mathrm{CH}$ is a spectrum of defective thyroid gland development (thyroid dysgenesis) including so called 'athyrosis' (without visible thyroid tissue in imaging studies), thyroid ectopy (frequently located in a sublingual position), hypoplasia (remnants of thyroid tissue in the normal position) and also hemithyroidoea. These forms represent $75-85 \%$ of all cases of permanent $\mathrm{CH}(3-5)$, while defects of thyroid hormone biosynthesis characterized by a normal sized or enlarged thyroid gland in the normal position are present in only $15-20 \%$ of the patients. A classification which is based solely on the results of imaging studies is in many instances not conclusive, because the available studies have limitations. For example, thyroid scintigraphy, which is based on the presence of functional thyroid tissue, fails to detect remnants of hypo- or non-functioning thyroid tissue. Therefore, the term 'apparent athyrosis' (6) has been created to describe patients with no visible thyroid tissue in thyroid scans but demonstration of a thyroid gland remnant in ultrasound studies as well as measurable serum L-thyroxine and thyroglobulin concentrations.
Therefore, the results of the serum measurements of thyroid hormones and thyroglobulin should be taken into account when a classification of $\mathrm{CH}$ is performed.

Reports on associated birth defects in patients with permanent $\mathrm{CH}$ vary in their frequencies ranging from a slight increase of $2.4 \%$ (7) in comparison with the normal population up to significantly increased frequencies of $20-25 \%(8,9)$. More recent studies have shown that the increased risk of associated malformations, especially of congenital heart defects in patients with permanent $\mathrm{CH}$, is limited to patients with thyroid dysgenesis (3). However, so far no patient with a known molecular defect of a transcription factor responsible for the embryonic development of the heart has been described who also suffered from severe $\mathrm{CH}$. Therefore, it remains a challenge to identify the molecular cause in patients with thyroid dysgenesis and congenital heart defects. It is also not explained why female patients are more frequently affected by thyroid dysgenesis than males and it is discussed controversially if a female preponderance is present only in certain forms of dysgenesis $(3,6)$, suggesting different molecular causes. On the other hand, if a female preponderance is observed in all forms of thyroid dysgenesis, they might represent a spectrum of different degrees of severity of the same underlying molecular defect.

\section{Central hypothyroidism}

Central hypothyroidism is estimated to occur in 1 in 50000 newborns. The most prevalent cause of central hypothyroidism is a defective development of the 
Table 1 Epidemiology and diagnosis of the different types of $\mathrm{CH}$.

\begin{tabular}{|c|c|c|c|c|c|}
\hline Type of $\mathrm{CH}$ & $\begin{array}{l}\text { Ultrasound } \\
\text { appearance }\end{array}$ & Thyroid scan & Serum TSH & Serum T4 & Serum TG \\
\hline \multicolumn{6}{|l|}{ Thyroid dysgenesis } \\
\hline Athyrosis & No thyroid tissue & No uptake & Increased & Undectable to very low & Undectable to very low \\
\hline Ectopy & No thyroid tissue & Ectopic uptake & Increased & Low to low normal & Low to normal \\
\hline Hypoplasia & Hypoplastic remnant & No uptake & Increased & Undectable to low normal & Undectable to normal \\
\hline $\begin{array}{l}\text { Defects of } \\
\text { hormone } \\
\text { biosynthesis }\end{array}$ & $\begin{array}{l}\text { Normal or } \\
\text { enlarged } \\
\text { thyroid }\end{array}$ & $\begin{array}{l}\text { No uptake or normal } \\
\text { uptake; normal or } \\
\text { enlarged volume }\end{array}$ & Increased & Undectable to low normal & Undectable to increased \\
\hline $\begin{array}{l}\text { Central } \\
\text { hypothyroidism }\end{array}$ & $\begin{array}{l}\text { Hypoplastic } \\
\text { gland }\end{array}$ & $\begin{array}{l}\text { Decreased uptake; } \\
\text { decreased volume }\end{array}$ & $\begin{array}{l}\text { Undetectable } \\
\text { or low }\end{array}$ & $\begin{array}{l}\text { Undectable } \\
\text { to low normal }\end{array}$ & $\begin{array}{l}\text { Undectable to } \\
\text { normal }\end{array}$ \\
\hline
\end{tabular}

T4, thyrosine; TG, triglycerides.

hypothalamus or pituitary leading to multiple pituitary hormone deficiencies. It has been formerly suggested that an impaired mental development in patients with central hypothyroidism might be due to episodes of hypoglycaemia caused by adrenal insufficiency or growth hormone $(\mathrm{GH})$ deficiency. In some patients with mutations of transcription factors involved in the development of the pituitary as well as of other structures of the nervous system, the loss of function of these transcription factors resulted in neurological symptoms independently of the lack of thyroid hormones or glucocorticoids. On the other hand, the identification of $\beta$-thyrotrophin (TSH) mutations in isolated central hypothyroidism has led to the new understanding that central hypothyroidism alone can lead to substantial and irreversible central nervous system (CNS) defects. However, the severity of clinical hypothyroidism varies in different genotypes and it remains to be elucidated why some mutations result in more severe defects than others.

\section{Inheritance of $\mathbf{C H}$}

$\mathrm{CH}$ in the era of newborn screening remains a sporadic disease and is not regarded as a hereditary disorder because familial occurrence is rare. Even in patients with putative autosomal recessive defects of thyroid hormone biosynthesis familial cases have been described rarely and systematic molecular genetic studies of candidate genes of thyroid hormone biosynthesis in patients with normally developed or enlarged thyroid glands are scarce. Therefore, no data on the epidemiology of the different defects of thyroid hormone biosynthesis or on the possible modes of inheritance are available so far.

Recent studies have described autosomal recessive inheritance (6) and familial dominant occurrence of thyroid dysgenesis (10). Moreover, an increased frequency of minor abnormalities of the development of the thyroid and pharyngeal derivatives has been described in first-degree relatives of patients with $\mathrm{CH}$ due to thyroid dysgenesis (11). But again epidemiological data on the prevalence of familial thyroid dysgenesis are scarce, but it has become apparent that thyroid dysgenesis, at least in a subset of the patients (so far in less than $5 \%$ ) is caused by molecular genetic defects, which in principle are inheritable. It is in the majority of patients, however, that a non-Mendelian genetic defect or somatic mutations have to be considered as possible mechanisms.

\section{Genetic defects in thyroid development}

Studies of mouse models with targeted disruption of genes involved in the development of the thyroid gland have provided insight in the molecular mechanisms of organogenesis and thereby are the basis for molecular genetic studies in human patients affected by thyroid dysgenesis $(12,13)$. In mice, organogenesis and migration have been shown to be dependent on the normal expression and interplay of at least four different transcription factors: HEX, NKX2.1, PAX-8 and FOXE-1. Targeted mutagenesis of these transcription factors in mice furthermore has demonstrated associated developmental defects of other organs because none of these factors is exclusively expressed in the thyroid.

The PAX-8 gene belongs to a family of genes which is characterized by a highly conserved paired-box DNA binding domain, which encodes for proteins, with an important role in the entire embryonic development. PAX-8 is expressed in the thyroid primordium, the mid- and hindbrain region and in the developing kidney. Mice homozygous for disruption of the PAX-8 gene are characterized by severe hypothyroidism and a small hypoplastic thyroid remnant without follicular structures (14). If these mice are not rescued with thyroid hormone replacement they die shortly after birth, but although PAX-8 is expressed also in the kidney and the CNS no obvious abnormalities of these organs have been described in homozygous or heterozygous knock-out animals. Screening for mutations in the PAX-8 gene of patients with $\mathrm{CH}$ has led to the identification of several patients with heterozygous mutations which are inherited in a dominant fashion (15-17). Most patients do not present other developmental 
defects, but in two unrelated male patients one hypoplastic kidney and one renal agenesis was observed. In the families of patients with $\mathrm{CH}$ due to PAX-8 mutations other carriers of heterozygous mutations had only mild adult-onset hypothyroidism or were euthyroid, indicating incomplete penetrance, which has been reported also in other disorders related to defects of PAX proteins (16). It remains to be elucidated if the presence of renal abnormalities in a few patients is just coincidental or can be explained by additional defects, e.g. in the PAX-2 gene, because PAX-8 - /mice present with renal abnormalities if they carry heterozygous or homozygous loss-of-function mutations of the PAX-2 gene (18).

FKHL15/FOXE-1 belongs to a family of transcription factors characterized by a forkhead DNA binding domain. In mice with homozygosity for targeted disruption of the FOXE-1 gene both thyroid agenesis and thyroid ectopy was identified, indicating that also in humans athyrosis and ectopy may be regarded as different degrees of severity of the same molecular defect. Furthermore, these mice have a cleft palate, which makes their feeding impossible and therefore early neonatal death is unavoidable (12). While screening of the FOXE-1 gene of patients with $\mathrm{CH}$ without associated problems failed to demonstrate any mutation (19), the study of two siblings with the so-called 'Bamforth syndrome' (20) including athyrosis and $\mathrm{CH}$, developmental delay, cleft palate, choanal atresia, bifid epiglottis and spiky hair demonstrated homozygosity of a loss-of-function mutation of the FOXE-1 gene in both siblings (21). Up to now only three different families with mutations have been described due to the autosomal recessive inheritance of severe loss-of-function mutations (22). In other patients with cleft palate and $\mathrm{CH}$, no mutations could be identified, therefore mutations, e.g. affecting FOXE-1 gene expression, might still be present in patients not presenting the complete syndromic picture.

The NKX2.1 (TTF-1, TITF-1 or T/ebp) gene encodes for a transcription factor of the homeobox domain containing genes of the NKX2 family. NKX2.1 is expressed in the thyroid, forebrain, basal ganglia, pituitary and the lung. Targeted disruption of both NKX2.1 alleles led to a complex phenotype of newborn mice (13). These mice die shortly after birth because of respiratory distress resulting from a defective lung development with insufficient surfactant production. While homozygous newborn mice were lacking any thyroid tissue at birth (athyrosis), heterozygous mice exhibited no abnormalities of thyroid development. In addition, in the homozygous mice the pituitary was completely absent and the development of the hypothalamic region was abnormal. Due to the early death of homozygous mice a study of hypothalamic-pituitary function or neurological testing could not be performed. The search for mutations in the NKX2.1 gene in patients with $\mathrm{CH}$ did not reveal abnormalities (23).
However, two studies were published on patients with deletions of chromosome $14 \mathrm{q} 13$ and $14 \mathrm{q} 12-13.3$ encompassing the NKX2.1 locus, who presented with mild hyperthyrotrophinaemia, neonatal respiratory distress and pulmonary problems as well as unexplained ataxia and muscular hypotonia $(24,25)$. However, in these reports it was suggested that the neurological problems observed in the patients might be due to the deletion of other genes located in the deleted chromosomal regions. These descriptions encouraged the investigation of the NKX2.1 gene of patients with $\mathrm{CH}$, in whom the long-term outcome, despite an early onset of treatment and adequate dosage, was unfavourable due to pulmonary complications, severe muscular hypotonia and neurological symptoms, which were defined as choreoathetosis and in some patients due to mental retardation. So far in six of such patients heterozygous mutations of the NKX2.1 gene have been identified (26). The phenotype of thyroid and pulmonary manifestations covers a wide spectrum ranging from hyperthyrotrophinaemia, to severe $\mathrm{CH}$ due to thyroid agenesis, and severe neonatal respiratory distress syndrome requiring ventilation, to a slight increase in pulmonary infections, while choreoathetosis presents with less phenotypical variation. Recently, familial benign choreoathetosis without accompanying pulmonary or thyroid disorders has been attributed to NKX2.1 mutations as well (27). In respect of the severe phenotype of the NKX2.1 knock-out mice, homozygosity for NKX2.1 mutations in humans is probably not viable. The mechanism by which heterozygous mutations cause the phenotype is most likely haploinsufficiency. Although the heterozygous NKX2.1 mice previously have been reported to be unaffected, a more recent study describes abnormalities of thyroid function and neurological development in heterozygous mice (28). The phenotypical variation observed in patients with heterozygous NKX2.1 mutations can be due to modifier genes with a different expression in different genetic backgrounds. Thus a new syndrome of $\mathrm{CH}$, pulmonary problems and the predominant symptom of choreoathetosis could be attributed to mutations of the NKX2.1 gene. These recent results have implications for the prognosis of patients with $\mathrm{CH}$ detected by newborn screening because the identification of defects of molecular mechanisms resulting in a defective development of the thyroid gland as well as of other organ systems will probably explain the less favourable outcome of some patients with $\mathrm{CH}$.

\section{Molecular defects in $\mathrm{CH}$ due to hypothalamic and pituitary defects}

Table 2 summarizes molecular mechanisms causing thyroid dysgenesis and Table 3 summarizes molecular mechanisms of central hypothyroidism.

Several defects of the hypothalamic-pituitary axis can be expected in patients with central hypothyroidism. 
Table 2 Molecular defects leading to thyroid dysgenesis.

\begin{tabular}{|c|c|c|c|}
\hline & PAX-8 & FOXE-1 & NKX2.1 \\
\hline Protein family & Paired domain transcription factor & Forkhead domain transcription factor & Homeodomain transcription factor \\
\hline Expression pattern & Thyroid; mid- and hindbrain; kidney & Thyroid; anterior pituitary & Thyroid; forebrain; pituitary; lung \\
\hline $\begin{array}{l}\text { Phenotype in } \\
\text { knock-out mice }\end{array}$ & Thyroid hypoplasia; early death & $\begin{array}{l}\text { Thyroid agenesis or thyroid } \\
\text { hypoplasia; cleft palate; early } \\
\text { death }\end{array}$ & $\begin{array}{l}\text { Thyroid agenesis; pituitary aplasia; } \\
\text { forebrain defects; disturbed lung } \\
\text { development; neonatal death }\end{array}$ \\
\hline $\begin{array}{l}\text { Human thyroid } \\
\text { phenotype }\end{array}$ & $\begin{array}{l}\text { Thyroid hypoplasia; } \\
\text { cystic rudiments; } \\
\text { ectopy; severe to mild } \mathrm{CH}\end{array}$ & Thyroid agenesis; severe $\mathrm{CH}$ & $\begin{array}{l}\text { Thyroid agenesis; thyroid hypoplasia; } \\
\text { normal thyroid; severe to } \\
\text { moderate } \mathrm{CH} \text {; hyperthyrotrophinemia }\end{array}$ \\
\hline $\begin{array}{l}\text { Manifestation } \\
\text { in other human } \\
\text { organs }\end{array}$ & $\begin{array}{l}\text { Developmental defect of the } \\
\text { kidneys }\end{array}$ & $\begin{array}{l}\text { Cleft palate; bifid epiglottis; } \\
\text { choanal atresia; spiky hair }\end{array}$ & $\begin{array}{l}\text { Choreoathetosis; respiratory distress; } \\
\text { pulmonary infections; } \\
\text { mental retardation }\end{array}$ \\
\hline Inheritance & Autosomal dominant & Autosomal recessive & Autosomal dominant \\
\hline
\end{tabular}

Table 3 Molecular defects causing central hypthyroidism.

\begin{tabular}{|c|c|c|c|c|}
\hline & $\beta$-TSH & PoU1F1 & Prop-1 & LHX3 \\
\hline Chromosome & $1 \mathrm{p} 13$ & $3 p 11$ & $5 q$ & $9 q 34$ \\
\hline Inheritance & Autosomal recessive & $\begin{array}{l}\text { Autosomal recessive } \\
\text { or autosomal dominant }\end{array}$ & Autosomal recessive & Autosomal recessive \\
\hline $\begin{array}{l}\text { Pituitary } \\
\text { hormone } \\
\text { deficiency }\end{array}$ & TSH & TSH; GH; prolactin & $\begin{array}{l}\text { TSH; GH; prolactin; } \\
\text { gonadotrophin } \\
\text { (corticotropin?) }\end{array}$ & $\begin{array}{l}\text { TSH; GH; prolactin; } \\
\text { gonadotrophin }\end{array}$ \\
\hline $\begin{array}{l}\text { Other } \\
\text { manifestations }\end{array}$ & $\begin{array}{l}\text { Mental retardation? } \\
\text { (sensorineural } \\
\text { deafness?) }\end{array}$ & Mental retardation? & Pituitary mass & $\begin{array}{l}\text { Rigid cervival spine; limited head } \\
\text { rotation; mental retardation? } \\
\text { Pituitary mass }\end{array}$ \\
\hline
\end{tabular}

It can be assumed that loss-of-function mutations of several genes would lead to selective central hypothyroidism: (pre-pro)-thyrotrophin-releasing hormone (TRH), TRH receptor and $\beta$-TSH gene.

\section{TRH and TRH receptor}

The human TRH gene has been mapped to chromosome 3q13.3.-q21, but no human mutations have been described so far. It is possible that humans with a TRH defect probably will present with a rather complex phenotype due to the unpredictable symptoms of central TRH deficiency and deficiencies of other cleavage peptides of the pre-pro-TRH molecule. Targeted disruption of the TRH gene in mice led to an unexpected mild phenotype with central hypothyroidism and hyperglycaemia (29).

So far only one family with compound heterozygosity for loss-of-function mutations of the TRH receptor gene with central hypothyroidism has been described. The affected patient presented with severe $\mathrm{CH}$, short stature and mental retardation, but initiation of treatment was delayed (30).

\section{TSH}

$\mathrm{CH}$ caused by mutations in the TSH $\beta$-chain is rare. Loss-of-function mutations of the $\beta$-TSH gene present with a variable phenotype. Some patients only have mild $\mathrm{CH}$ (31, 32), while others present with severe symptoms already in the neonatal period and are mentally retarded if thyroid hormone substitution is delayed. TSH is very low or immeasurable and cannot be stimulated by TRH. The most prevalent mutation identified in different populations, which results in severe $\mathrm{CH}$, is a $1 \mathrm{bp}$ deletion $(\mathrm{T})$ from codon 105 (TGT) of the $\beta$-TSH gene, converting a cysteine to a valine residue $(\mathrm{C} 105 \mathrm{~V})$ and yielding an additional eight amino acid non-homologous peptide extension on the mutant protein (33).

\section{Developmental defects of the pituitary}

Defects of pituitary development result in various forms of impaired secretion of pituitary hormones. Usually the clinical picture is characterized by multiple hormone deficiencies including TSH; however, the time course of manifestations of the different hormone deficiencies is highly variable and therefore congenital hypothyroidism may be the first and leading symptom of a defective hypothalamic-pituitary development.

\section{Pit-1}

Pit-1 (human homologue: POU1F1) is a transcription factor important for pituitary development and 
pituitary hormone expression. Two animal models of Pit-1 defects, the Snell and Jackson mice, are characterized by deficiencies of GH, prolactin and TSH. Several reports on humans with loss-of-function mutations in the transcription factor Pit-1 have documented severe $\mathrm{CH}$ as the leading symptom in the newborn period with a delayed manifestation of GH deficiency (34, 35). The mode of inheritance is autosomal recessive if the mutation is located in the DNA binding domain, while other mutations with a dominant negative effect are inherited in an autosomal dominant manner.

\section{Prop-1}

The expression of another pituitary specific transcription factor Prop-1 (Prophet of pit-1) identified in the Ames mice precedes the expression of Pit-1. Prop-1 deficiency results in impaired GH, prolactin and TSH but also gonadotrophin secretion. Autosomal recessive inheritance of loss-of-function mutations in patients with combined pituitary hormone deficiencies have been reported (36). However, the severity of the phenotype varies widely and the manifestation of the different hormone deficiencies follows an unpredictable time course. Severe $\mathrm{CH}$ as the leading symptom so far has not been described.

\section{LHX 3}

More recently, we were able to describe the first human mutations of the LHX3 gene encoding for a LIM homeodomain containing transcription factor involved in the development of the anterior pituitary (37). Previously, targeted disruption of the LHX3 gene in mice had resulted in a disturbed development of the anterior pituitary with conserved function of the corticotrophs. In these consanguineous pedigrees, the mutations were inherited homozygously. In contrast, in screening for mutations in sporadically occurring combined pituitary hormone deficiencies no abnormalities of the LHX3 gene were identified. Most importantly, as a peculiar finding, a short neck with limited ability to rotate the head was observed in all affected children but no abnormality of the spine could be visualized on X-ray or magnetic resonance imaging. In these patients $\mathrm{CH}$ was the first and leading symptom, which preceded the diagnosis of $\mathrm{GH}$ or gonadotrophin deficiency. Thus $\mathrm{CH}$ due to hypothalamic-pituitary defects can be caused by different molecular mechanisms. However, the symptoms can be as severe as in primary $\mathrm{CH}$ and a delayed treatment can result in irreversible mental retardation.

\section{Summary}

These recent results have implications for the counselling of parents and patients with $\mathrm{CH}$ detected by newborn screening. With the rapid advancement of diagnostic tools for molecular genetic studies it should
Table 4 Unsolved problems in the genetics of $\mathrm{CH}$.

Which are the causes for the increased prevalence of thyroid dysgenesis in females?

Do the different types of $\mathrm{CH}$ represent different molecular defects or do they represent the phenotypical spectrum of the same defects?

Can the increased frequency of congenital heart defects in patients with congenital hypothyroidism be explained by mutations in a certain candidate gene?

Is there a genotype-phenotype correlation in patients with a mutation, e.g. the $\beta$-TSH gene, causing central hypothyroidism?

Could epigenetic mechanisms or somatic mutations represent plausible explanations for the sporadic occurence of $\mathrm{CH}$ caused by thyroid dysgenesis?

be possible in the near future to include the investigation of candidate genes in the diagnostic work-up to ensure a correct counselling of the parents and early focused support for affected patients. From the current knowledge it is a valid hypothesis that longterm consequences for some patients with $\mathrm{CH}$ despite early and adequate treatment might result from a common defect in thyroid and brain development rather than from fetal or perinatal hypothyroidism.

$\mathrm{CH}$ in the era of newborn screening so far has remained a sporadic disease and is in general not regarded as a hereditary disorder because familial occurrence has remained rare. It will be interesting to conduct systematic follow-up studies regarding the heredity of $\mathrm{CH}$ in the first generation detected by newborn screening, because they will presumably have a normal reproduction rate, while in the era before newborn screening late-diagnosed patients with severe $\mathrm{CH}$ had a significantly reduced reproduction. The prevalence of identifiable disease-causing mutations, however, is very low and, as mentioned before, many questions regarding the molecular pathogenesis remain unsolved.

Table 4 lists unsolved problems in the genetics of $\mathrm{CH}$.

Since the majority of patients with $\mathrm{CH}$ due to thyroid dysgenesis are not affected by the syndromic types of $\mathrm{CH}$ caused by mutations in known transcription factors, still unidentified genes may be involved or a complex trait of inheritance has to be postulated for $\mathrm{CH}$. Moreover, the presence of somatic mutations is another possible pathomechanism. Therefore, in general, $\mathrm{CH}$ due to thyroid dysgenesis can be considered as a hereditary disorder, but the mode of inheritance and the modifying genetic and environmental factors are far from being clarified. Further systematic studies are necessary to assess the prevalence of mutations in known candidate genes for thyroid organogenesis and hypothalamicpituitary development in patients presenting with $\mathrm{CH}$.

\section{Acknowledgements}

The work was supported by DFG 5FB577. The longstanding fruitful collabaration with Prof. R Di Lauro and Dr I Netchine is acknowledged. 


\section{References}

1 Roberts HE, Moore CA \& Fernhoff PM. Population study of congenital hypothyroidism and associated birth defects. Atlanta, 19791992. American Journal of Medical Genetics 199771 29-32.

2 Lorey FW \& Cunningham DC. Birth prevalence of congenital hypothyroidism by sex and ethnicity. Human Biology 199264 531- 538 .

3 Devos H, Rodd C, Gagne N, Laramboise R \& Van Vliet G. A search for possible mechanisms of thyroid dysgenesis: sex ratios and associated malformations. Journal of Clinical Endocrinology and Metabolism 199984 2501-2506.

4 Grüters A, Finke R, Krude H \& Meinhold H. Etiological grouping of congenital hypothyroidism with a thyroid gland in situ. Hormone Research 199441 3-9.

5 Vassart G, Dumont JE \& Refetoff S. Thyroid disorders. In The Metabolic and Molecular Basis of Inherited Disease, pp 2917-2918. Eds CR Sciver. AL Beaudet, WS Sly \& D Valle. New York: McGraw Hill, Inc., 1995.

6 Gagne N, Parma J, Deal C, Vassart G \& Van Vliet G. Apparent athyrosis contrasting with normal plasma $\mathrm{Tg}$ and associated mutations of the TSH receptor gene. Are athyrosis and ectopic thyroid distinct entities? Journal of Clinical Endocrinology and Metabolism 199883 1771-1773.

7 Chanoine JP, Bourdoux P \& Delange F. Congenital anomalies associated with hypothyroidism. Archives of Disease in Childhood 198661 1147-1148.

8 Fernhoff PM, Brown AL \& Elsas L. Congenital hypothyroidism and increased risk of neonatal morbidity results in delayed treatment. Lancet 19878531 490-491.

9 Siebner R, Merlob P, Kaiserman I \& Sack J. Congenital abnormalities concomitant with persistent permanent $\mathrm{CH}$. American Journal of Medical Genetics $1992 \mathbf{4 4} 57-60$.

10 Castanet M, Polak M \& Bonaiti-Pellie C. Nineteen years of nationa screening for congenital hypothyroidism: familial cases with thyroid dysgenesis suggest involvement of genetic factors. Journal of Clinical Endocrinology and Metabolism 200186 2009-2014.

11 Leger J, Marinovic D, Garel C, Bonaiti-Pellie C, Polak M \& Czernichow P. Thyroid developmental anomalies in first degree relatives of children with congenital hypothyroidism. Journal of Clinical Endocrinology and Metabolism 200287 575-580.

12 de Felice M, Ovitt C \& Biffali E. A mouse model for hereditary thyroid dysgenesis and cleft palate. Nature Genetics 199819 395-398.

13 Kimura S, Hara Y, Pineau T, Fernandez-Salguero P, Fox CH, Ward JM \& Gonzalez FJ. The T/ebp null mouse: thyroid specific enhancer binding protein is essential for the organogenesis of the thyroid, lung, ventral forebrain and pituitary. Genes and Development $1996 \mathbf{1 0} 60-69$.

14 Mansouri A, Chowdry K \& Gruss P. Follicular cells of the thyroid gland require PAX-8 function. Nature Genetics 199819 87-90.

15 Macchia PE, Lapi P, Krude H, Pirro MT, Missero C \& Chiovato L. PAX8 mutations associated with congenital hypothyroidism caused by thyroid dysgenesis. Nature Genetics 199819 83-86.

16 Congdon T, Nguyen LQ, Nogueira CR, Hibiby RL, Medeiros-Neto G \& Kopp P. A novel mutation (Q40P) in PAX8 associated with congenital hypothyroidism and thyroid hypoplasia. Journal of Clinical Endocrinology and Metabolism $2001863962-3967$.

17 Vilain C, Rydlewski C, Duprez L, Heinrichs C, Abramowicz M, Malvaux P, Renneboog B, Parma J, Costagliola S \& Vassart G. Autosomal dominant transmission of thyroid hypoplasia due to loss-of-function mutations of PAX8. Journal of Clinical Endocrinology and Metabolism 200186 234-238.

18 Bouchard M, Souabni A, Mandler M, Neubuser A \& Busslinger M. Nephric lineage specification by Pax2 and Pax8. Genes and Development $2002162958-2970$.

19 Macchia PE, Mattei MG, Lapi P, Fenzi G \& Di Lauro R. Cloning, chromosomal localization and identification of polymorphisms in the human TTF2 gene. Biochimie $1998 \mathbf{8 1} 433-440$.

20 Bamforth JS, Hughers IA, Lazarus J, Weaver CM \& Harper PS. Congenital hypothyroidism, cleft palate and spiky hair. Journal of Medical Genetics 198926 49-60.
21 Clifton-Bligh RJ, Wentworth J \& Heinz P. Mutation of the gene encoding human TTF-2 associated with thyroid agenesis, cleft palate and choanal atresia. Nature Genetics $199819399-401$.

22 Castanet M, Park SM, Smith A, Bost M, Leger J, Lyonnet S, Pelet A, Czenichow P, Chatterjee K \& Polak M. A novel loss-of-function mutation in TTF-2 is associated with congenital hypothyroidism, thyroid agenesis and cleft palate. Human Molecular Genetics 2002 15 2051-2059.

23 Lapi P, Macchia PE, Chiovato L, Biffali E, Moschini L, Larizza D, Baserga M, Pinchera A, Fenzi G \& Lauro R. Mutations in the gene encoding TTF-1 are not a frequent cause of congenital hypothyroidism due to thyroid dysgenesis. Thyroid 19977 383-387.

24 Devriendt K, Vanhole C, Matthijs G \& de Zegher F. Deletion of TTF-1 gene in an infant with neonatal thyroid dysfunction and respiratory failure. New England Journal of Medicine 1999338 $1317-1318$.

25 Iwatani N, Mabe H, Devriendt K et al. Deletion of the NKX2.1 gene encoding for TTF1 in two siblings with hypothyroidism and respiratory failure. Journal of Pediatrics 2000137 271-276.

26 Krude H, Schutz B, Biebermann H \& Von Moers A. Choreoathetosis, hypothyroidism and pulmonary problems due to NKX2.1 haploinsufficiency. Journal of Clinical Investigation 2002109 475-480.

27 Breedveld GJ, van Dongen JW, Krude H, Gruters A \& Heutink P. Mutations of the TTF-1 are associated with benign hereditary chorea. Human Molecular Genetics 200215 971-979.

28 Pohlenz J, Dumitrecu A, Zundel D, Martine U, Schonberger W, Koo E, Weiss R, Cohen RN, Kimura S \& Refetoff S. Partial deficiency of TTF-1 produces predominantly neurological defects in men and mice. Journal of Clinical Investigation 2002109 469-473.

29 Yamada M, Saga Y, Shibusawa N, Hirato J, Murakami M, Iwasaki T, Hashimoto K, Satoh T, Wakabayashi K, Taketo MM \& Mori M. Tertiary hypothyroidism and hyperglycemia in mice with targeted disruption of the releasing hormone gene. PNAS $1997 \mathbf{9 4}$ $10862-10867$

30 Collu R, Tang J, Castagne J. Lagace G, Masson N \& Huot C. A novel mechanism for isolated central hypothyroidism: inactivating mutations in the thyrotropin-releasing hormone receptor gene. Journal of Clinical Endocrinology and Metabolism 199782 1361-1365.

31 Hayashizaki Y, Hiraoka Y, Endo Y \& Matsubara K. Thyroidstimulating hormone (TSH) deficiency caused by a single base substitution in the CAGYC region of the beta-subunit. EMBO Journal $198982291-2296$.

32 Dacou-Voutetakis C, Feltquate D, Drakopoulou M, Kourides IA \& Dracopoli NC. Familial hypothyroidism caused by a nonsense mutation in the thyroid-stimulating hormone beta-subunit gene. American Journal of Human Genetics 199046 988-993.

33 Biebermann H, Liesenkotter KP, Emeis M, Obladen M \& Gruters A. Severe congenital hypothyroidism due to a homozygous mutation of the beta TSH gene. Pediatric Research 199946 170-173.

34 Blankenstein O, Muhlenberg R, Kim C, Wuller S, Pfaffle R \& Heimann G. A new C-terminal located mutation (V272ter) in the PIT-1 gene manifesting with severe congenital hypothyroidism. Possible functionality of the pit-1 C-terminus. Hormone Research 200156 81-86.

35 Tatsumi K, Miyai K, Notomi T, Kaibe K, Amino N, Mizuno Y \& Kohno H. Cretinism with combined hormone deficiency caused by a mutation in the PIT1 gene. Nature Genetics $1992156-58$.

36 Wu W, Cogan JD, Pfäffle R, Dasen JS, Frisch H \& O'Connell SM. Mutations of the Prop- 1 gene cause familial combined pituitary hormone deficiency. Nature Genetics 200119 147-149.

37 Netchine I, Sobrier ML, Krude H, Schnabel D, Maghnie M, Marcos E. Duriez B. Cacheux V, Moers A. Goossens M. Gruters A \& Amselem S. Mutations in LHX3 result in a new syndrome revealed by combined pituitary hormone deficiency. Nature Genetics $200025182-186$.

Received 18 May 2004

Accepted 23 September 2004 